\begin{tabular}{|c|c|c|}
\hline Baseline characteristics & MTX-Starters & Biologic-starters \\
\hline $\mathrm{N}$ & 686 & 346 \\
\hline Age, years & $59(49,67)$ & $59(51,67)$ \\
\hline Female, $\mathrm{N}(\%)$ & $441(64.3)$ & $269(77.8)$ \\
\hline Disease duration, months & $9(4,27)$ & $72(24,180)$ \\
\hline \multicolumn{3}{|l|}{ Smoking: } \\
\hline Never & $240(35.5)$ & $106(30.6)$ \\
\hline Former & $265(39.1)$ & $163(47.1)$ \\
\hline Current & $172(25.4)$ & $77(22.3)$ \\
\hline Swollen joint count (28) & $5(2,10)$ & $8(5,11)$ \\
\hline Tender joint count (28) & $5(2,11)$ & $13(9,18)$ \\
\hline $\mathrm{CRP}, \mathrm{mg} / \mathrm{l}$ & $7(3,19)$ & $10(5,26)$ \\
\hline DAS28-CRP & $4.2(3.3,5.2)$ & $5.6(5.2,6.2)$ \\
\hline $\mathrm{HAQ}$ & $1.13(0.50,1.63$ & $1.63(1.13,2.00)$ \\
\hline Pain VAS, mm & $50(26,73)$ & $69(52,78)$ \\
\hline Fatigue VAS, mm & $51(24,72)$ & $71(52,85)$ \\
\hline Anti-CCP+, N (\%) & $686(100)$ & $346(100)$ \\
\hline Anti-CCP titre & $147(48,416)$ & $138(37,492)$ \\
\hline
\end{tabular}

Anti-CCP = ant - -cyclic citrullinated peptide antibody, $C R P=C$-reactive protein, $D A S 28=$

Disease Activity Score (28), HAQ = Health Assessment Questionnaire, $M T X=$ methotrexate,

$N=$ number, $V A S=$ visual analogue scale

Disclosure of Interests: James Gwinnutt: None declared, Kimme Hyrich Grant/research support from: Grants to institution: BMS, Pfizer, UCB, Mark Lunt: None declared, Darren Plant: None declared, Nisha Nair: None declared, Anne Barton: None declared, Suzanne Verstappen: None declared

DOI: 10.1136/annrheumdis-2019-eular.4724

\section{THU0669 GESTATIONAL AGE AT BIRTH AND THE RISK OF AUTOIMMUNE DISEASE}

Petteri Hovi ${ }^{1}$, Suvi Alenius ${ }^{2}$, Pieta Näsänen-Gilmore ${ }^{2}$, Mika Gissler ${ }^{2}$ Eero Kajantie ${ }^{2} .{ }^{1}$ National Institute for Health and Welfare, Health, Helsinki, Finland; ${ }^{2}$ National Institute for Health and Welfare, Helsinki, Finland

Background: A preterm newborn has an immature immune system. Although preterm birth is associated with autoimmune hypothyreosis, it is unclear, whether it also could lead to an overall increased risk of autoimmune disease.

Objective: We assessed whether a shorter gestation increases the risk of special reimbursement for medication for hypothyreosis, rheumatic disease, or ulcerative colitis/Crohn's disease

Design/Methods: A total of 235622 children were born in Finland from Jan 1987 to Sep 1990, according to the Medical birth register, which provided also gestational age (GA) at birth. Data were linked by help of the personal identity number. A register held by the Social Insurance Institution provided the data on special reimbursements. We calculated cumulative incidences within gestational age groups until December 2014 and tested statistical significance by the chi-squared -test.

Results: At the end of the follow-up, 1354 men and 2200 women had at least one of the specified autoimmune diseases.

The cumulative incidences differed by gestational age only regarding a $50 \%$ higher incidence for hypothyreosis among all subgroups of preterm wome $(P=0.05)$. No other clear patterns were seen regarding autoimmune diseases among preterm born or early term born subgroups.

Conclusion(s): Those born preterm develop hypothyreosis more often. However, the two other composite categories of autoimmune diseases were unrelated to gestational age pointing against an overall tendency toward autoimmune disease in preterm born young adults.

Cumulative incidence $(1 / 100,000)$ of four groups of autoimmune diseases

\begin{tabular}{cccccc}
\hline & & Hypoth $^{104}$ & Rheuma $^{202}$ & UC\&CD $^{208}$ & $\mathrm{n}$ \\
\hline Men & $0<31$ & 0 & 597 & 398 & 1005 \\
132 or 33 & 263 & 658 & 395 & 760 \\
234 to 36 & 206 & 494 & 762 & 4856 \\
3 37 & 149 & 512 & 776 & 6057 \\
4 38 & 140 & 504 & 625 & 15687 \\
539 to 41 & 122 & 550 & 692 & 85753 \\
$6>41$ & 120 & 519 & 798 & 5010
\end{tabular}

\begin{tabular}{|c|c|c|c|c|c|}
\hline & 99 missing & 0 & 512 & 448 & 1563 \\
\hline & Total & 128 & 539 & 687 & 120690 \\
\hline & $\begin{array}{l}\text { P-value } \\
\left(\mathrm{Chi}^{2}\right)\end{array}$ & 0.40 & 0.99 & 0.49 & \\
\hline \multirow[t]{10}{*}{ Women } & $0<31$ & 649 & 519 & 389 & 771 \\
\hline & 132 or 33 & 651 & 163 & 814 & 614 \\
\hline & 234 to 36 & 771 & 795 & 675 & 4149 \\
\hline & 337 & 502 & 929 & 799 & 5380 \\
\hline & 438 & 537 & 975 & 692 & 14152 \\
\hline & 539 to 41 & 460 & 1056 & 704 & 83712 \\
\hline & $6>41$ & 278 & 1069 & 684 & 4678 \\
\hline & 99 missing & 474 & 880 & 609 & 1477 \\
\hline & Total & 478 & 1021 & 702 & 114932 \\
\hline & $\begin{array}{l}\text { P-value } \\
\left(\mathrm{Chi}^{2}\right)\end{array}$ & 0.05 & 0.16 & 0.95 & \\
\hline
\end{tabular}

202 Disseminated connective tissue disorders, rheumatoid arthritis and other rheumatic diseases (A04.6, A39.8, A50.5, D76.0, D76.3, H20.1, H30, I33.0, I40.8, J84, K50.9, K51.9, K73.2, K74.3, K83.0, L40.5, M02, M05, M06, M08, M13.9, M30-M35, M45, M46.1, M46.9, M94.1, N03, N04, Q44.2).

104 Hypothyreosis

208 Ulcerative colitis or Crohn's disease

Disclosure of Interests: : Petteri Hovi Consultant for: Pfizer, Paid instructor for: Pfizer, Suvi Alenius: None declared, Pieta Näsänen-Gilmore: None declared, Mika Gissler: None declared, Eero Kajantie: None declared DOI: 10.1136/annrheumdis-2019-eular.8269

\section{THU0670 PATERNAL USE OF METHOTREXATE AND CONGENITAL MALFORMATIONS: A SYSTEMATIC REVIEW AND META-ANALYSIS}

Thomas Bo Jensen ${ }^{1,2}$, Mikkel Bring Christensen ${ }^{1,3}$, Nicole Tsao ${ }^{2,4}$, Seoyoung $\mathrm{Kim}^{2,4}$, Jon Trærup Andersen ${ }^{1,3} .{ }^{1}$ Copenhagen University Hospital Bispebjerg, Department of Clinical Pharmacology, Copenhagen, Denmark ${ }^{2}$ Brigham and Women s Hospital, Division of Pharmacoepidemiology and Pharmacoeconomics, Boston, United States of America; ${ }^{3}$ University of Copenhagen, Faculty of Health and Medical Sciences, Copenhagen, Denmark; ${ }^{4}$ Harvard Medical School, Boston, United States of America

Background: Maternal exposure to methotrexate (MTX) during pregnancy is known to be teratogenic, but less is known about the risk due to paternal MTX exposure. Because of a theoretical teratogenic risk from paternal exposure, treatment recommendations advocate that men should discontinue MTX three months before conception and continue discontinuation during the partners' pregnancy. This may lead to suboptimal adherence to treatment, fear among the future parents and pregnancy termination.

Objectives: The aim was to systematically review and meta-analyze the collective data on paternal MTX exposure and the risk of congenital malformations.

Methods: We performed a systematic search in the databases - PubMed, Embase, Cochrane Central, and Cinahl - on March 1, 2018. We included studies with an English abstract that assessed major or all (both major and minor) malformations following any paternal exposure to MTX. Studies that included a contro group were included in the meta-analysis. No time restriction was applied. Review Manager Version 5.3 was used for the meta-analysis.

Results: We identified 36 studies assessing the risk of congenital malformations following paternal exposure to MTX of which 20 contained original data. Five studies met the inclusion criteria for the meta-analysis: Three studies from Denmark had a major overlap in study populations, one study from Norway, and one German study. All studies were cohort studies using national registries except the German that used structured interviews and phone interviews. Because of the overlapping Danish studies, only the largest Danish study for each of the outcomes were included. We included a total of 265 fathers exposed to MTX and $1,004,834$ controls in the meta-analysis investigating risk of major congenital malformations. Among the offspring of the MTX-exposed $7(2.64 \%)$ had a major malformation compared to $33,816(3.37 \%)$ among the unexposed. Pooled odds ratios were $1.02(95 \%$ confidence interval $[\mathrm{Cl}] 0.48$ 2.20) for major malformations and $1.02(\mathrm{Cl}$ 0.62-1.66) for all malformations.

Conclusion(s): In this systematic review and meta-analysis, we found no association between preconceptional paternal MTX use and major or all congenital malformations. The current recommendations to avoid paternal MTX use before conception do not appear to be supported by evidence and paternal treatment with MTX could be continued when planning a pregnancy.

Disclosure of Interests: Thomas Bo Jensen: None declared, Mikkel Bring Christensen: None declared, Nicole Tsao: None declared, Seoyoung Kim 